\title{
Aplikasi Diagnosa Penyakit Pada Ternak Ayam Menggunakan Metode Forward Chaining Berbasis Web
}

\author{
Hidayat Muhammad Nur ${ }^{1}$ *, Vadlya Maarif ${ }^{2}$, Ina Maryani ${ }^{3}$, Yesi Gusmiati ${ }^{4}$ \\ 1,4 Sistem Informasi, Universitas Bina Sarana Informatika Indonesia \\ ${ }^{2,3}$ Sistem Informasi, Universitas Nusa Mandiri Indonesia \\ *Corresponding Author.E-mail:hidayat.hmm@bsi.ac.id
}

\begin{abstract}
Abstraksi
Berternak ayam selalu dihadapkan kepada ragam penyakit, diagnosa yang muncul secara umum melewati gejala fisik. Intensitas dan langkah untuk meminimalisasi keterlambatan penangganan ataupun kerugian yang disebabkan penyakit ayam para peternak dan warga masyarakat. Dalam upaya mengatasi permasalahan tersebut, dibuatlah entitas sistem yang dapat membantu kelompok masyarakat yang terlibat ternak ayam, dengan menerapkan metode forward chaining yang menjadikan pemahaman ilmu pakar kedalam komputer sehingga sistemis dapat mengerjakan solusi bagaikan ahli atau pakar. Dengan adanya sistem pakar ini kelak diharapkan dapat menggalakkan kegiatan peternak dalam mendiagnosa penyakit ayam. Pengembangan sistem pakar dibangun dengan menggunakan metode waterfall yang terdiri rekayasa dan pemodelan sistem, analisis sistem, desain, perancangan antarmuka dan pengujian. Implementasi metode sistem pakar menggunakan forward chaining ialah proses premis data inputan berbentuk indikasi sehingga dapat menuju akurasi diagnosis terkena penyakit, beserta jalan keluar perihal usulan pengobatan dan pencegahan dengan dasar pengamatan gejala. Hasil penelitian pada aplikasi ini terdapat entitas yaitu gejala, penyakit, data penyakit, kandang ayam, konsultasi, diagnosa penyakit, solusi.
\end{abstract}

Kata Kunci : Aplikasi, Sistem Pakar, Metode Forward Chaining, Penyakit Ayam, Website

\begin{abstract}
Raising chickens is always faced with a variety of diseases, the diagnosis of which appears generally through physical symptoms. Intensity and steps to minimize delays in handling or losses caused by chicken diseases for farmers and community members. To overcome these problems, a system entity was created that can help community groups involved in raising chickens, by applying the forward chaining method that makes the understanding of expert knowledge into a computer so that systematists can work on solutions like experts. With this expert system, it is hoped that it will be able to promote the activities of farmers in diagnosing chicken diseases. Expert system development is built using the waterfall method which consists of system engineering and modeling, system analysis, design, interface design, and testing. Implementation of the expert system method using forward chaining is the premise process of input data in the form of indications so that it can lead to an accurate diagnosis of disease, along with solutions regarding proposed treatment and prevention based on symptom observation. The results of research in this application contain entities, namely symptoms, diseases, disease data, chicken coop, consultation, disease diagnosis, solutions.
\end{abstract}

Keywords: Applications, Expert Systems, Forward Chaining Methods, Chicken Diseases, Websites 


\section{Introduction}

Ayam merupakan hewan unggas yang banyak dipelihara masyarakat dari cara tradisional hingga peternakan besar (Tullah et al., 2016). Dengan populasi yang banyak maka penyakit yang menyertainya juga semakin kompleks, dari penyakit ringan hingga penyakit menular kepada manusia dan mengakibatkan kematian seperti penyakit flu burung. Karena rentan terhadap serangan penyakit hewan berbahaya. Oleh sebab itu masih ditemukan banyak unggas khususnya ayam di peternakan yang mendadak mati. Banyak peternakan besar ataupun hanya dipelihara masyarakat secara tradisional yang mengalami kerugian. Masyarakat menjadi resah karena penyakit berbahaya dari ayam yang dapat menular ke manusia atau sifat zoonosis (Santo Faskafri, 2020) akibat mengkonsumsi daging ayam yang sudah terjangkit penyakit.

Maka dari itu perlu adanya penanganan dini untuk pemecahan masalah penyakit ayam, seiring berkembangnya teknologi komputer. Dengan sistem maka semakin aktif peranan komputer sebagai kecerdasan buatan. Bidang teknik kecerdasan buatan yang cukup diminati adalah sistem pakar (expert system). Sistem pakar adalah program komputer yang dirancang untuk pengambilan keputusan. secara umum sistem yang berusaha mengadopsi pengetahuan manusia ke komputer, agar komputer dapat memecahkan masalah seperti yang biasa dilakukan oleh para pakar atau ahli (Merlina, 2016) . Diharapkan sistem ini dapat menyelesaikan masalah tertentu tanpa bantuan para ahli dalam bidang tersebut. Sedangkan untuk para ahli, sistem ini dapat digunakan sebagai asisten. Sistem pakar berupa perangkat lunak pengambil keputusan yang dapat mencapai tingkat performa yang sebanding dengan seorang pakar atau dalam berbagai bidang yang khusus.

Beberapa peneliti sebelumnya berfokus membuat sistem pakar untuk membantu mendiagnosa penyakit ayam. Dibangunnya sistem tersebut menjadi acuan, jika ayam terjangkit penyakit diharapkan dapat teridentifikasi secara cepat dan dapat melakukan penanganan yang tepat. Sehingga perawatan dan pemeliharaan yang intensif pada ayam akan menghasilkan keuntungan. (Riyadi, 2016) berfokus pada 5 sampel data penyakit untuk pengujian akurasi pada penyakit ayam serama, kampung dan ayam ras berikut analisa dan perancangan berbasis proses dengan 8 entitas dalam bentuk PDM (Ratih Fitri Aini, 2016). Menganalisa sistem berjalan yang digunakan dari satu case diagram, kemudian diusulkan menjadi 3 case diagram representasi pengetahuan dengan menggunakan kaidah produksi yaitu 
bagian premis (If) dan bagian konklusi (If_Then) pada studi kasus pembuatan sistem pakar di PT. Kemiri Jaya Farm (Tullah et al., 2016)

Belum ada peneliti lain yang membahas tentang kompleksitas diari diagnose penyakit ternak ayam. Oleh karena itu, dalam penelitian ini intens untu membahas pada pengembangan aplikasi diagnose penyakit pada ternak ayam meliputi gejala, penyakit, data penyakit, konsultasi, diagnose penyakit, solusi. Tujuan dari penelitian ini adalah menerapkan metoda forward chaining dengan 11 entitas untuk sistem pakarnya sehingga dapat meningkatkan akurasi dan kompleksitas diagnosis penyakit yang dihasilkan. Berikut mengadopsi pengetahuan pakar kedalam komputer sehingga komputer dapat menyelesaikan masalah seperti layaknya seorang pakar.

\section{Materials and Methods}

Data input penelitian diperoleh dari peternakan ayam rizki gemilang di daerah Desa Sambeng Wetan, Kembaran, Banyumas. Mengenai metode pengembangan perangkat lunak dan pengumpulan data adalah sebagai berikut :

\subsection{Metode Pengembangan Sistem}

Air terjun (Waterfall) sering disebut juga model sekuensial linier atau alur hidup klasik. (Larasati et al., 2017) Model air terjun menyediakan pendekatan alur hidup perangkat lunak secara sekuensial atau terurut dimulai dari analisa kebutuhan, desain, pengkodean, pengujian dan pendukung pemeliharaan. Seperti di ilustrasikan dengan gambar berikut :

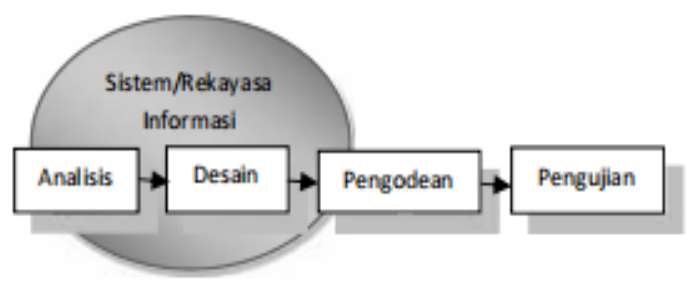

Gambar 2.1. Tahapan Model Waterfall

Berikut penjelasan tahapan model waterfall:

1. Analisis berupa kebutuhan fungsional dan non fungsional yang ditulis pada dokumen.

2. Dilanjutkan membuat struktur navigasi, entity relationship diagram (ERD) dan logical record structure (LRS) untuk memudahkan pembuatan website pada tahapan desain.

3. Kemudian menerapkan desain yang telah dibuat ke dalam program perangkat lunak.

4. Langkah pengujian dengan menggunakan blackbox testing. Hal ini dilakukan untuk meminimalisir kesalahan (error) dan memastikan aplikasi berbasis website yang dibuat telah sesuai dengan yang dibutuhkan.

\subsection{Metode Pengumpulan Data}

Studi ini dilakukan dengan cara mengunjungi lokasi yang akan diteliti dan 
pengumpulan data dilakukan secara langsung, meliputi :

1) Wawancara

Teknik pengumpulan data dengan cara mengadakan tanya jawab (Prapitasari et al., 2019), dengan narasumber peternakan ayam rizki gemilang terkait untuk mendapatkan data profil dan permasalahan yang diperoleh.

2) Observasi

(Syarwani, 2017) Teknik pengumpulan data dengan melakukan pengamatan, terhadap objek ternak ayam pada peternakan.

\section{3) Studi Pustaka}

Penggunaan buku, berkas dan pencarian literatur pada media internet berkaitan dengan judul yang diangkat sebagai referensi yang erat kaitannya dengan tema penelitian.

\section{Results and Discussion}

Penelitian ini mendapatkan hasil berupa aplikasi diagnosa penyakit ternak ayam dengan detail tiga akses pengguna (Madiistriyatno, 2018), yaitu administrator, super admin dan karyawan (user), lima rancangan dokumen masukkan dan tiga rancangan dokumen keluaran, delapan spesifikasi file, sebagai identifikasi, pemanggilan, pengisian data maupun kolom untuk memudahkan pengelolaan data secara terinci digunakan pengkodean, pengoperasian aplikasi dijalankan menggunakan atau berbasis web. Terpaut jumlah input data aturan dengan penelitian yang terdahulu oleh (Riyadi, 2016). Sebagai halnya penelitian (Ratih Fitri Aini, 2016) berpusat pada jumlah relasi antara data gejala, penyakit dan kategori permasalahan. Hasil penelitian kami juga menampilkan hasil atau riwayat diagnosa, penyakit ayam riwayat per kandang, dan mencetak informasi.

\subsection{Rancangan Entity Relationship Diagram}

Database dibagi kedalam beberapa tabel pada kebutuhan pengelolaan dan pengembangan (Imaniawan \& Nur, 2019). Tabel-tabel tersebut akan diimplementasikan menjadi sebuah gambar seperti berikut :

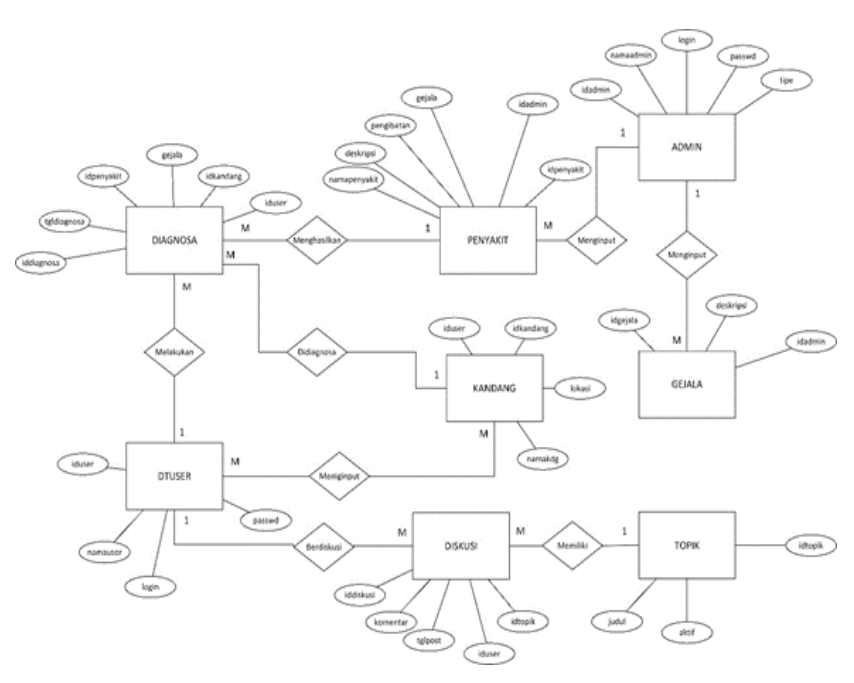

Gambar 3.1. ERD Aplikasi

\subsection{Implementasi}

Implementasi rancangan interface pada aplikasi diagnosa penyakit ternak ayam 
mengikuti hasil rancangan antarmuka.

1) Halaman Login Administrator

Merupakan halaman input user dan password untuk mengakses menu utama. Login berhasil, sehingga menampilkan Implementasi halaman sebagai berikut :

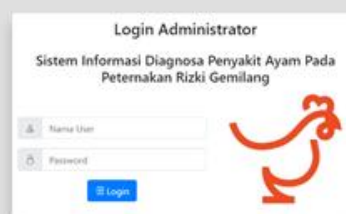

Gambar 3.2. Implementasi Halaman

\section{Login Administrator}

2) Halaman Dashboard Administrator

Merupakan halaman awal setelah berhasil melakukan login. Berisi beranda dan menu khusus untuk admin. Implementasi halaman dashboard admin sebagai berikut:

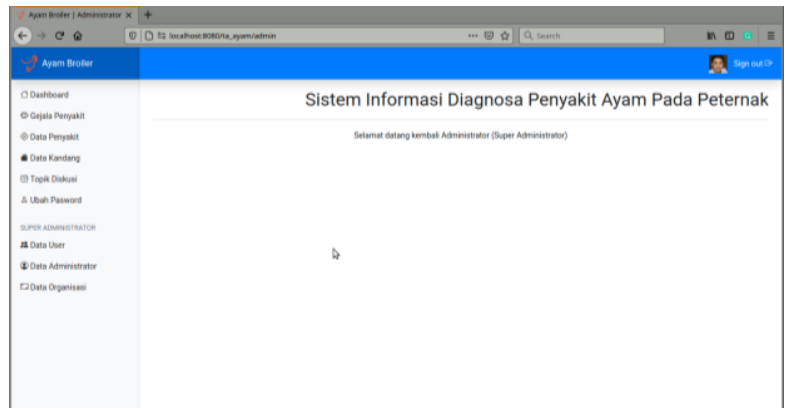

Gambar 3.3. Implementasi Halaman

\section{Dashboard Administrator}

3) Halaman Data Gejala Penyakit

Berisikan data gejala penyakit lima halaman yang sudah di input oleh admin (add, edit, delete). Implementasi halaman data gejala penyakit seperti berikut :

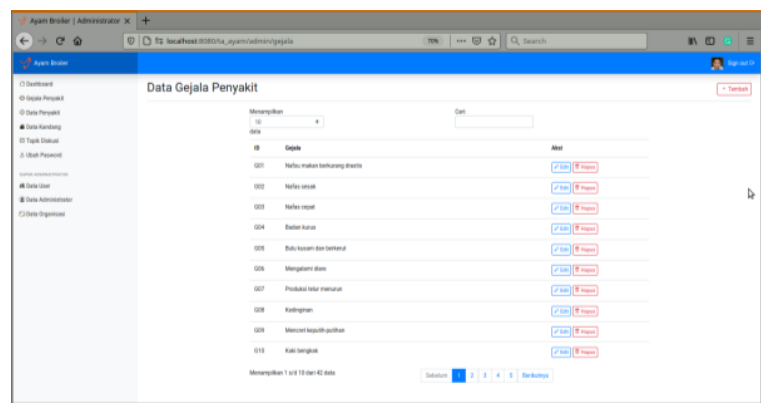

Gambar 3.4. Implementasi Halaman

Data Gejala Penyakit

4) Halaman Data Penyakit

Berisikan dua halaman data penyakit dan akses ubah, hapus, tambah. Implementasi

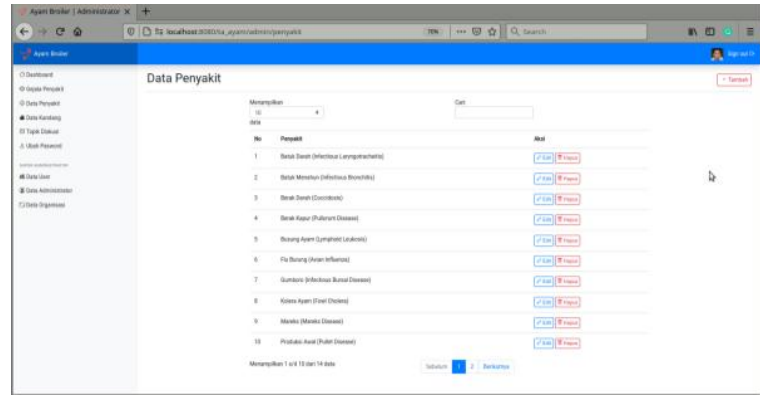

halaman data penyakit sebagai berikut:

Gambar 3.5. Implementasi Halaman

Data Penyakit

5) Halaman Penyakit Ayam

Implementasi halaman penyakit ayam seperti berikut :

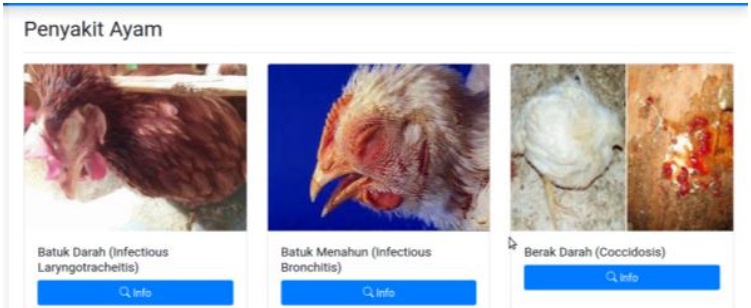

Gambar 3.6. Implementasi Halaman

Penyakit Ayam

6) Halaman Diagnosa Penyakit 
Berisikan daftar diagnose penyakit ayam pada kandang melati. Implementasi sebagai berikut:

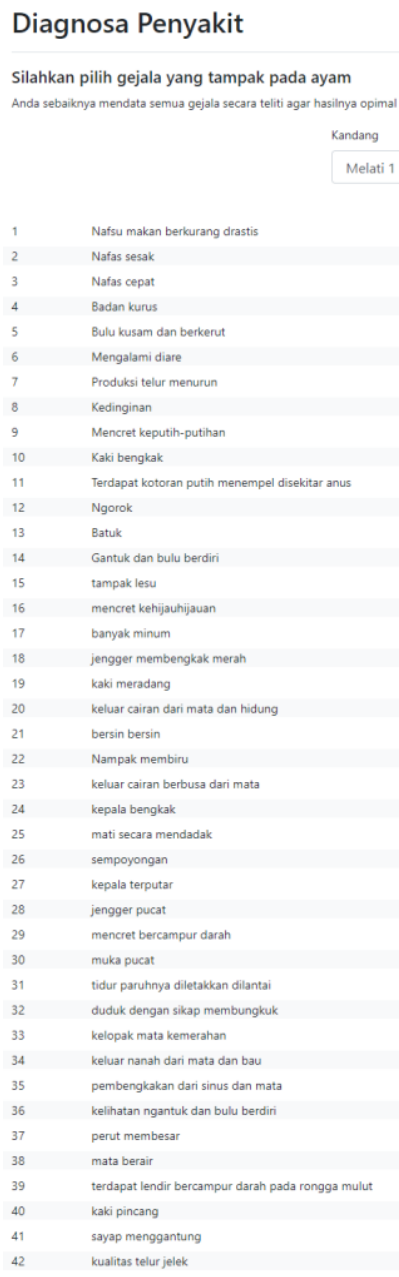

Gambar 3.7. Implementasi Halaman

Diagnosa Penyakit

\section{7) Halaman Hasil Pengujian}

Setelah user memilih gejala yang sesuai, diproses kemudian menampilkan hasil pengujian penyakit ayam yaitu penyakit teridentifikasi. Implementasi hasil, gambar

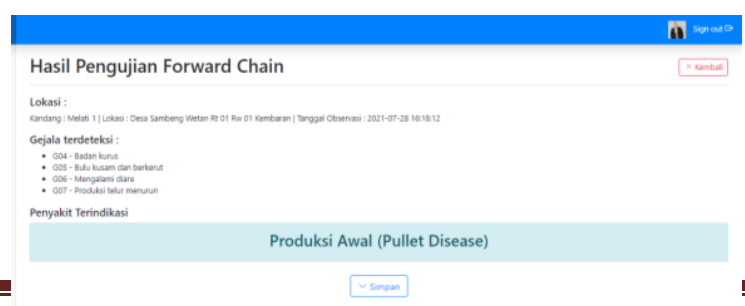

seperti berikut :

Gambar 3.8. Implementasi Halaman Hasil Pengujian

8) Halaman Riwayat Diagnosa

Berisi informasi hasil riwayat diagnosa penyakit ayam yang telah di diagnosa. User dapat melihat dan mencetak informasi pada halaman ini. Implementasi riwayat diagnosa sebagai berikut:

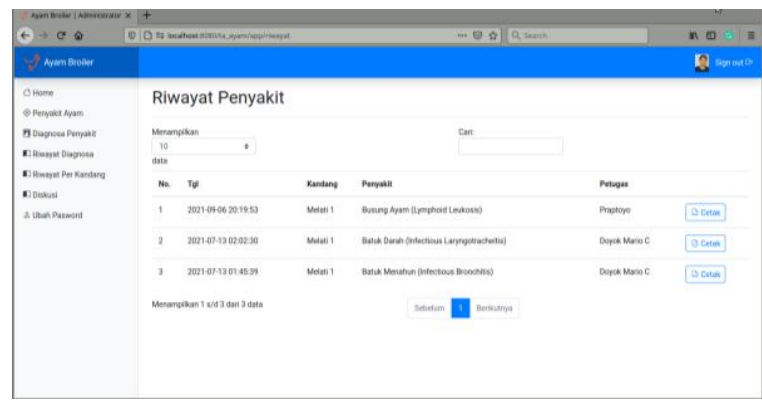

Gambar 3.9. Implementasi Halaman Riwayat Diagnosa

9) Halaman Riwayat Per Kandang

Berisi informasi kandang yang terdapat ayam sakit. User dapat melihat dan mencetak. Implementasi tampilan halaman

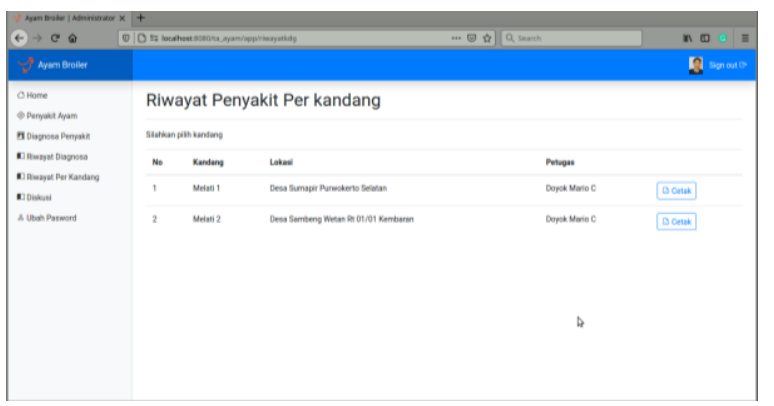

riwayat kandang berikut dibawah ini:

Gambar 3.10. Implementasi Halaman Riwayat Kandang

10) Pengujian Unit

Menjelaskan mengenai pengujian sistem yang dibuat menggunakan blackbox testing 
proses input dan output. Terlampir hasil contoh form penting dalam aplikasi pada tabel 3.1. Hasil Blackbox Admin Tambah Gejala Penyakit.

\section{Kesimpulan}

Menurut hasil penelitian setelah memanfaatkan metode pengembangan perangkat lunak waterfall, termasuk diataranya dilakukan pengujian blackbox antara lain yaitu :

1. Memperoleh sebentuk aplikasi diagnose penyakit pada ternak ayam berbasis web.

2. Sistem akan mengenali penyakitpenyakit yang diderita ayam berdasarkan gejala-gejala yang Nampak dan menjadi alat bantu para peternak ayam.

3. Secara teoritis pada aplikasi ini dimungkinkan penambahan modul, fitur dan penggunaan metode Bayesian network atau certainly factor disesuaikan kebutuhan yang berlaku dikemudian hari, untuk kebutuhan diagnosis, pengolahan dan inventarisir data penyakit ayam yang lebih kompleks pada peternakan dan masyarakat umum. Mengingat kelemahan utama metode forward chaining ialah tidak adanya cara untuk mengenali fakta penting dari fakta lain.

\section{Acknowledgment}

Diucapkan banyak terima kasih kepada Universitas Bina Sarana Informatika PSDKU Kabupaten Banyumas, Universitas Nusa Mandiri yang telah membantu berserta mendukung dalam periode penelitian ini. Terima kasih tidak lupa disampaikan kepada rekan penulis, sejawat dan pihak terkait atas kontribusi yang diberikan hingga penelitian dapat berjalan dengan baik.

\section{Referensi}

[1] Imaniawan, F. F. D., \& Nur, H. M. (2019). Perancangan Dan Pembuatan Website Penjualan Biji Kopi Pada Society Coffee House Purwokerto. EVOLUSI - Jurnal Sains Dan Manajemen, 7(1), 61-67. https://doi.org/10.31294/evolusi.v7i1.5 $\underline{030}$

[2] Larasati, H., Masripah, S., Bsi, A., Merdeka, B. J., Tengah, B., Jl, J. R., Fatmawati, N., \& Selatan, J. (2017). Dengan Metode Waterfall. Jurnal Pilar Nusa Mandiri, 13(2), 193-198.

[3] Madiistriyatno, H. (2018). Pengamanan Pengelolaan Hak Akses Web Berbasis Yii Framework. SYNTAX Jurnal Informatika, 7(1), 5263.

[4] Merlina. (2016). BAB II TINJAUAN PUSTAKA 2.1 Sistem. 5-16.

[5] Prapitasari, I., Utami, K., Setyarini, R., ... S. A.-J. K., 2017, undefined, 
Pandiana, L., Komunitas, S. N.-J. K., \& 2018, undefined. (2019). Bab Iii Metodologi Penelitian. 62-76.

[6] Ratih Fitri Aini, M. H. M. M. (2016). Perancangan Sistem Pakar Diagnosa Penyakit Ayam Dengan Metode Forward Chaining. J I M P - Jurnal Informatika Merdeka Pasuruan, 1(2). https://doi.org/10.37438/jimp.v1i2.21

[7] Riyadi, L. (2016). Sistem Pakar Diagnosa Penyakit Ayam Berbasis Web Menggunakan Metode Forward Dan Backword Chaining. Jurnal SISTEMASI, 5(3), 29-35.

[8] Santo Faskafri. (2020). Bab 1 pendahuluan. Pelayanan Kesehatan, 2015 , 3-13. http://repository.usu.ac.id/bitstream/12 3456789/23790/4/Chapter I.pdf

[9] Syarwani, S. L. (2017). Sistem Info Rmasi Penjualan Berbasis Web Pada C V Pinasthika Khatulistiwa Kubu Raya. 175.45.187.195, 71. ftp://175.45.187.195/TitipanFiles/BAHAN WISUDA PERIODE V 18 MEI 2013/FULLTEKS/PD/lovita meika savitri (0710710019).pdf

[10] Tullah, R., Mariana, A. R., \& Christian, E. S. (2016). Sistem Pakar Penyakit Ayam Negeri (Studi Kasus di PT Kemiri Jaya Farm). Jurnal Sisfotek Global, 6(1), 42-44. https://journal.stmikglobal.ac.id/index. php/sisfotek/article/view/94 